\title{
MODEL JARINGAN SARAF TIRUAN UNTUK EVALUASI RESIKO KREDIT
}

\author{
Novan Wijaya \\ Manajemen Informatika, AMIK Multi Data Palembang, \\ Jl. Rajawali No.14, 30113, Palembang \\ E-mail:novan.wijaya@mdp.ac.id
}

\begin{abstract}
Abstrak
Evaluasi resiko kredit adalah topik yang penting dalam manajemen resiko keuangan dan menjadi sorotan utama dalam industry perbankan. Penelitian ini membahas sebuah sistem evaluasi resiko kredit dengan menggunakan model jaringan saraf tiruan berdasarkan algoritma back propagation. Sistem ini melatih dan menguji jaringan saraf untuk menentukan nilai prediksi dari resiko kredit apakah beresiko tinggi atau beresiko rendah. Jaringan saraf ini menggunakan 14 layer masukan, sembilan layer tersembunyi dan satu layer keluaran, dan data yang digunakan berasal dari bank yang memiliki kantor cabang di Jakarta Timur. Hasil penelitian menunjukan bahwa jaringan saraf dapat digunakan secara efektif dalam evaluasi resiko kredit dengan keakuratan sebesar $88 \%$ dari 100 data pengujian.
\end{abstract}

Kata kunci: jaringan saraf, backpropagation, resikokredit

\begin{abstract}
Credit risk evaluation is an importanttopic in financial risk management and become a major focus in the banking sector. This research discusses a credit risk evaluation system using an artificial neural network model based on backpropagation algorithm. This system is to train and test the neural network to determine the predictive value of credit risk, whether high riskorlow risk. This neural network uses 14 input layers, nine hidden layers and an output layer, and the data used comes from the bank that has branches in EastJakarta. The results showed that neural network can be used effectively in the evaluation of credit risk with accuracy of $88 \%$ from 100 test data.
\end{abstract}

Keywords : neural network, back propagation, credit risk

\section{PENDAHULUAN}

Evaluasi resiko kredit adalah topik yang penting dalam manajemen resiko keuangan dan menjadi sorotan utama dalam industry perbankan. Kredit dapat memberikan kontribusi yang positif dalam pendapatan bank, melalui bunga yang dibayar oleh debitur. Disisi lain kredit dapat memberikan kontribusi negative dalam menimbulkan kerugian bagi bank, karena timbulnya kredit-kredit bermasalah, sehingga menyebabkan semakin besarnya biaya pencadangan aktiva produktif yang harus disediakan oleh bank, dan mengurangi potensi laba yang akan diperoleh atau lebih jauh akan mengurangi modal yang tersedia pada bank tersebut. Jaringan saraf tiruan telah sukses digunakan dalam berbagai bidang, dan juga dalam bidang keuangan. Penggunaan jaringan saraf tiruan menjadi sangat populer di berbagai macam aplikasi bisnis termasuk penilaian kredit. Telah banyak penelitian yang berkembang dengan pesat tentang analisis resiko kredit, diantaranya dengan Linear Discriminant Analysis, Logit Analysis, Probit Analysis, Linear Programming, Integer Programming, K-Nearest Neighbor (KNN), Classification Tree, 
Artificial Neural Network (ANN), Genetic Algorithm (GA), Support Vector Machine (SVM)[1]. Penggunaan jaringan saraf tiruan dalam aplikasi bisnis telah diteliti sebelumnya oleh para peneliti dan jaringan saraf tiruan telah dipertimbangkan untuk menjadi alat yang teliti untuk analisis kredit diantara yang lain[2]. Didasari hal tersebut maka dilakukan penelitian mengenai model jaringan saraf tiruan untuk mengevaluasi resiko kredit dengan menggunakan metode backpropagation, karena kemampuan mengelola resiko yang handal merupakan salah satu factor kunci dalam menghantarkan kesinambungan hidup suatu bank.

\section{METODE PENELITIAN}

\subsection{Metode Pengumpulan Data}

Jenis data yang digunakan merupakan data sekunder yang berupa data resiko kredit yang meliputi CAR (Capital Adequacy Ratio), NPL (Non Performing Loans) dan PPAP (Penyisihan Penghapusan Aktiva Produktif) dan data-data kreditur yang telah mengajukan kredit. Jenis data tersebut di dapat dengan mengumpulkan dokumentasi dari hasil laporan "Performance Collection" pada sebuah bank. Data yang digunakan sebagai data indikator adalah data-data tahun 2007 sampai dengan 2009. Dan untuk data-data yang berupa atribut-atribut kreditur yang ingin mengajukan kredit di dapat dari form pengajunan kredit pada bank.

\subsection{Jaringan Saraf Tiruan}

Jaringan saraf tiruan (JST) adalah sebuah mesin yang memodelkan cara otak melakukan operasi tertentu. Jaringan ini biasanya di implementasikan dengan mengunakan komponenkomponen elektronik atau dapat juga disimulasikan dengan perangkat lunak pada sebuah komputer digital. JST dibentuk sebagai generalisasi model matematika dari jaringan saraf biologi, dengan asumsi bahwa [3]: pemrosesan informasi terjadi pada banyak elemen sederhana (neuron), sinyal dikirimkan diantara neuron-neuron melalui penghubung, penghubung antar neuron memiliki bobot yang akan memperkuat atau memperlemah dan untuk menentukan output, setiap neuron menggunakan fungsi aktivasi yang dikenakan pada jumlahan input yang diterima.

\subsection{Backpropagation}

Backpropagation merupakan salah satu metode pelatihan pada jaringan saraf, dimana ciri dari metode ini adalah meminimalkan error pada output yang dihasilkan oleh jaringan[4]. Backprogatioan memiliki beberapa unit yang ada dalam satu atau lebih layar tersembunyi (gambar 1) dengan $n$ buah masukan (ditambah sebuah bias), sebuah layar tersembunyi yang terdiri dari $p$ unit (ditambah sebuah bias), serta $m$ buah unit keluaran.

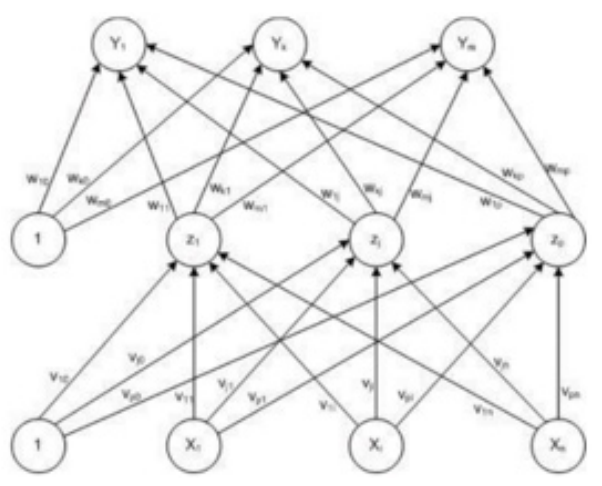

Gambar 1.Arsitektur Backpropagation[3] 
$\mathrm{V}_{\mathrm{ji}}$ merupakan bobot garis dari unit masukan $\mathrm{x}_{\mathrm{i}}$ ke unit layar tersembunyi $\mathrm{z}_{\mathrm{j}}\left(\mathrm{v}_{\mathrm{j} 0}\right.$ merupakan bobot garis yang menghubungkan bias di unit masukkan ke unit layar tersembunyi $\left.z_{j}\right)$. $w_{k j}$ merupakan bobot dari unit layar tersembunyi $z_{j}$ ke unit keluaran $y_{k}\left(w_{k j}\right.$ merupakan bobot dari bias di layar tersembunyi ke unit keluaran $\mathrm{z}_{\mathrm{k}}$ ).

\subsection{Kredit}

Perbankan adalah penyedian uang atau tagihan yang dapat dipesamakan dengan itu, berdasarkan persetujuan atau kesepakatan pinjam-meminjam antara bank dengan pihak lain yang mewajibkan pihak peminjam untuk melunasi utangkan setelah jangka waktu tertentu dengan pemberian bunga, termasuk : overdraft yaitu saldo negatif pada rekening giro nasabah yang tidak dapat dibayar lunas pada akhir tahun, pengambil-alihan tagihan dalam rangka kegiatan anjak piutang, dan pengambil-alihan atau pemelia kredit dari pihak lain[5]. Kredit yang disalurkan oleh bank dapat digolongkan berdasarkan jangka waktu, tujuan dan penggunaanya.

\subsection{Resiko Kredit}

Resiko kredit yang banyak terjadi di institusi keuangan adalah resiko akibat ketidakmampuan debitur untuk mengembalikan pinjaman dan membayar bunganya, serta penurunan performance kredit. Ketidakmampuan debitur tersebut terjadi akibat goodwill, musibah (force majure) ataupun akibat kesalah petugas kredit dalm memprediksi repaymentcapacity, sehingga terjadi kelebihan pemberian limit kredit. Berdasarkan peraturan bank indonesia ada beberapa indikator utama dalam memilai kredit perbankan yaitu Rasio Permodalan atau Capital Adequacy Ratio (CAR), Ratio Aktiva Produktif atau Non Performing Loan(NPL) dan PenyisihanPenghapusan Aktiva Produktif (PPAP)[6].

1. Rasio Permodalan (Capital Adequacy Ratio)

Ketentuan besarnya nilai CAR ditentukan minimum sebesar $8 \%$ berdasarkan Peraturan Bank Indonesia (PBI) nomor 3/21/PBI/2001 yang menggambarkan bahwa setiap 8 rupiah modal sendiri dapat menutupi 100 aktiva berisiko

2. Rasio Aktiva Produktif (Non Performing Loan)

Rasio ini menggambarkan besarnya kredit bermasalah yang terjadi dalam satu periode. Semaki kecil nilai NPL berarti semakin kecil pula kredit yang bermasalah. Nilai NPL maksimal sebesar 5\% berdasarkan PBI nomor 3/25/PBI/2001 di mana setiap 100 rupiah total kredit yang diberikan terdapat maksimum 5 rupiah kredit yang bermasalah.

3. Penyisihan Penghapusan Aktiva Produktif (PPAP)

PPAP adalah penyisihan yang wajib dibentuk oleh bank untuk menutupi resiko kerugian. Besarnya pembentukan PPAP sekurang-kurangnya adalah :

- $0.5 \%$ dari aktiva produktif yang digolongkan lancar

- $10 \%$ dari aktiva produktif yang digolongkan kurang lancar setelah dikurangi dengan nilai agunan yang dikuasi.

- $50 \%$ dari aktiva produkti yang digolongkan diragukan setelah dikurangi dengna nilai agunan yang dikuasi.

- 100\% dari aktiva produkti yang digolongkan macet yang masih tercatat dalam pembukuan BPR setelah dikurangi dengan nilai agunan yang dikuasai.

\subsection{Ratiounal Unified Process (RUP)}

Rational Unified Process (RUP) merupakan suatu metode rekayasa perangkat lunak yang proses pengembangan perangkat lunaknya mencakup secara keseluruhan dari perangkat lunak[7]. RUP secara jelas menugaskan siapa saja orang yang bertanggung jawab dalam rekayasa tersebut. RUP sendiri menggunakan sebuah konsep object oriented, dengan aktifitas 
yang berfokus pada pengembangan model dengan menggunakan Unified Model Language (UML).

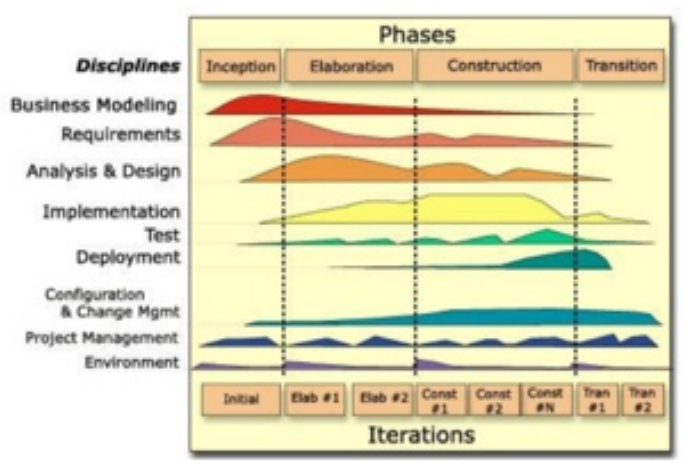

Gambar 2. Arsitektur Rational Unified Process [8]

Fase-fase dalam RUP antara lain :

1. Inception

Pada tahap ini akan menentukan usecase diagram pada sistem yang akan dikembangkan

2. Elaboration

- Merancang sequence diagram

- Merancang class diagram

3. Construction

- Mengimplementasikan rancangan berdasarkan dari fase-fase sebelumnya

- Melakukan pengujian

4. Transition

- Melakukan performance testing

- Merilis versi akhir sistem

\section{HASIL DAN PEMBAHASAN}

\subsection{Proses Pembelajaran Backpropagation}

Pada pembelajaran Backpropagation meliputi 3 fase yaitu fase pertama adalah fase propagasi maju, fase kedua adalah fase propagasi mundur dan fase yang ketiga adalah fase perubahan bobot. Arsitektur Backpropagation yang digunakan adalah dengan 3 layer dengan 1 layer masukan, 1 layer tersembunyi dan 1 layer keluaran. Pada fase layer masukan terdapat 14 node yang merupakan faktor-faktor yang mempengaruhi evaluasi resiko kredit, diantaranya adalah :

- Data-data calon kreditur yang meliputi data diri berupa pekerjaan, penghasilan, jumlah tanggungan, jumlah pinjamann, dan lain-lain.

- Data bank yang menjadi indikator dalam menilai kredit perbankan, yaitu rasio permodalan, Capital Adequacy Ratio (CAR), Rasio Aktiva Produktif, yaitu Non Performing Loan (NPL), Penyisahan Penghapusan Aktiva Produktif (PPAP).

- Data ekonomi yang meliputi nilai inflasi dan nilai tukar rupiah 


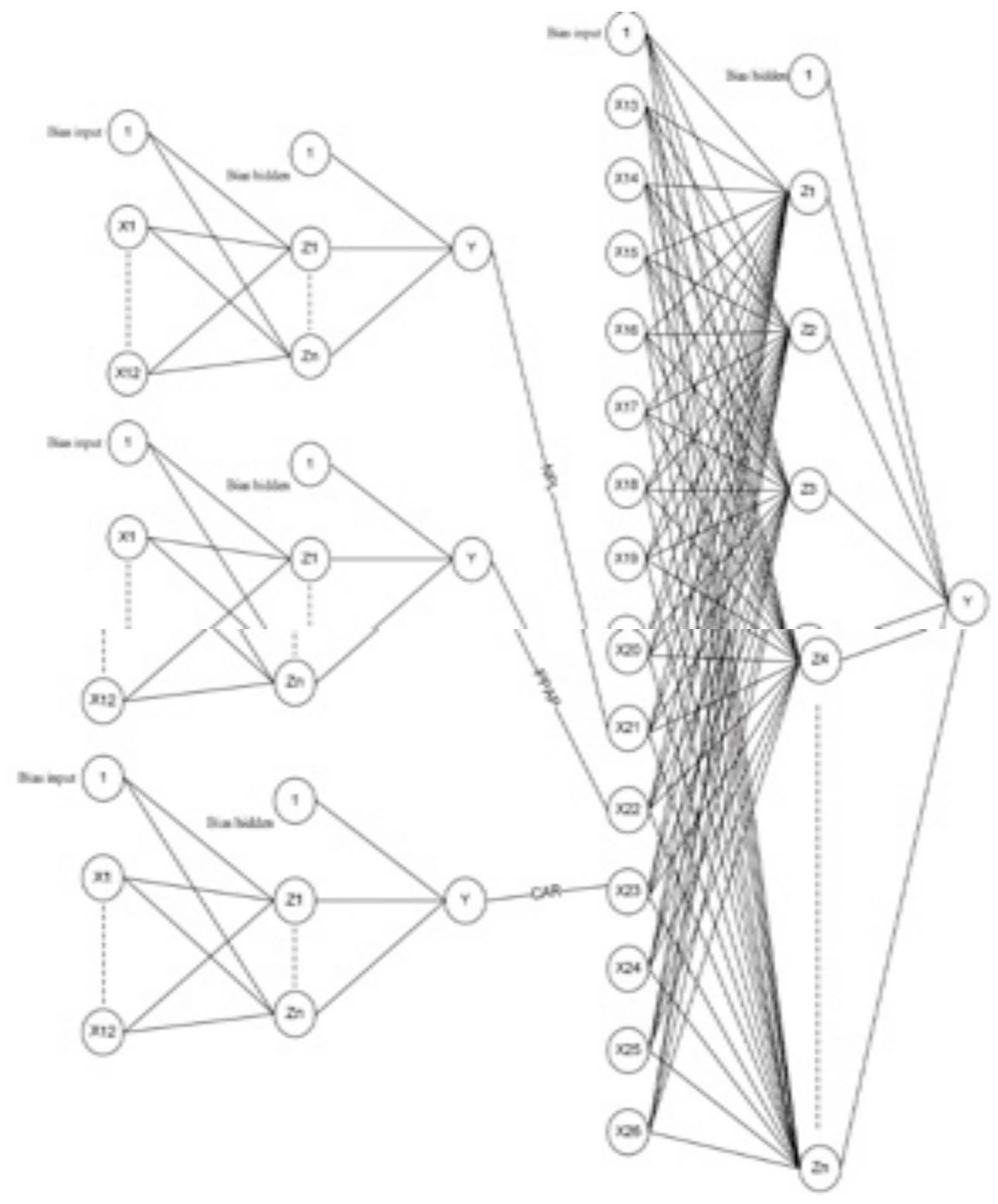

Gambar 3.Arsitekutr JST Resiko Kredit

Pada layer keluaran hanya terdapat satu buah node yaitu berupa nilai dari resiko kredit kreditur. Dan pada layer tersembunyi terdapat $n$ buah node yang ditentukan pada saat pembelajaran.

- X13 : Umur (direpresentasikan dengan membagi data dengan nilai maksimum data umum sampel pelatihan)

- X14 : Status Rumah (Sendiri, Sewa, Kredit, Orang Tua, Instansi, danLainnya, direpresentasikan dengan $1,2,3,4,5,6)$

- X15 : Jumlah Tanggungan (1,2,3,4, lebih dari 4, direpresentasikan dengan 1,2,3,4,5)

- X16 : Pekerjaan (PNS, Karyawan Swasta, Wiraswasta, BUMN, Profesional, Lainnya, direpresentasikan dengan 1,2,3,4,5,6)

- X17 : Penghasilan (direpresentasikan dengan membagi data dengan nilai maksimum data penghasilan sampel pelatihan)

- X18 : Penghasilan Pasangan (direpresentasikan dengan membagi data dengan nilai maksimum data penghasilan pasangan sampel pelatihan) 
- X 19 : Jumlah Pinjaman (direpresentasikan dengan membagi data dengan nilai maksimum data jumlah pinjaman sampel pelatihan)

- X 20 : Tempo Peminjaman (1 tahun, 2 tahun, 3 tahun, direpresentasikan dengan 1,2,3)

- X 21 : Nilai NPL (direpresentasikan dengan membagi data dengan nilai maksimum data NPL sampel pelatihan)

- X22 : Nilai PPAP (direpresentasikan dengan membagi data dengan nilai maksimum data PPAP sampel pelatihan)

- X23 : Nilai CAR (direpresentasikan dengan membagi data dengan nilai maksimum data CAR sampel pelatihan)

- X24 : Nilai Tukar Rupiah (direpresentasikan dengan 1 apabila nilai tukar rupiah naik, dan 0 apabila nilai tukar rupiah turun).

- X25 : Inflasi (direpresentasikan dengan memabgi data dengan nilai maksimum data nilai inflasi sampel pelatihan)

- X26 : Nilai Selisih Pemasukan dengan Pengeluaran (direpresentasikan dengan membagi data dengan nilai maksimum data nilai selisih pemasukan dengan pengeluaran sampel pelatihan).

- Y ; Variabel output erupa nilai resiko kredit apakah resiko kredit rendah, resiko kredit cukup tinggi atau sangat tinggi.

Untuk nilai data bank NPL, PPAP, dan CAR didapatkan dari laporan tahunan suatu bank, sehingga untuk mendapatkan nilai pada tahun yang akan datang digunakan forecasting. Untuk forecasting data tersebut arsitektur backpropagation yang digunakan adalah dengan 3 layer, 1 layer masukkan, 1 layer tersembunyi, dan 1 layer keluaran.

Pada layer masukkan terdapat 12 node yaitu X1 sampai X12 yang merupakan sebanyak nilai bulan dalam periode satu tahun. Pada layer keluaran hanya terdapat satu buah node yaitu nilai data bulan pertama pada periode berikutnya. Dan pada layer tersembunyi terdapat $n$ buah node yang ditentukan pada saat pembelajaran. Sebelum melakukan pembelajaran nilai-nilai pada layer masukkan di normalisasi terlebih dahulu agar nilai-nilai berada pada interval 0 dan 1. Pada arsitektur JST forecasting indikator data bank, rumus normalisasi yang digunakan adalah

$$
x^{\prime}=\frac{0,8(x-b)}{(a-b)}+0,1
$$

di mana :

$\mathrm{x}^{\prime}=$ data hasil normalisasi

$\mathrm{x}=$ data asli atau data awal

$\mathrm{a}=$ nilai maksimum data asli

$\mathrm{b}=$ nilai minimum data asli

Dan untuk arsitektur JST evaluasi resiko kredit rumus normalisasi yang digunakan adalah dengan membagi nilai data masukkan dengan nilai data maksimum pada data pembelajaran.

$$
x^{\prime}-\frac{x}{b}
$$

Bobot yang menghubungkan neuron pada layer masukkan dengan neuron pada layer tersembunyi adalah bobot $v$. Sedangkan bobot yang menghubungkan neuron pada layer tersembunyi ke neuron pada layer keluaran adalah bobot $w$. Bobot-bobot ini mengalami perubahan selama proses pembelajaran. Bobot-bobot hasil pembelajaran ini disimpan ke dalam databse untuk digunakan pada saat pengujian. Pada proses pembelajaran, nilai keluaran yaitu $Y$ digunakan untuk mengupdate bobot dan menghitung error. Proses pembelajaran selesai apabilai nilai epoch telah terpenuhi atau nilai targer MSE telah terpenuhi. 


\subsection{Proses Pengujian}

Pada proses pengujian dilakukan hal yang sama seperti proses pembelajaran. Akan tetapi tahapanyang digunakan hanya fase propagasi maju. Hasil dari pengujian berupa nilai keluaran Y yang akan di denormalisasi. Untuk forecasting indikator data bank denormalisasi yang digunakan adalah rumus kebalikan dari normalisasi, yaitu :

$$
x=\frac{(b-a)\left(x^{\prime}-0,1\right)}{0,8}+a
$$

Sedangkan untuk evaluasi resiko kredit apabila nilai Y lebih besar atau sama dengan 0.5 maka resiko kredit bernilai rendah, dan jila nilai $\mathrm{Y}$ berada di anatara 0.25 sampai 0.5 maka resiko kredit bernilai cukup tinggi, dan jika nilai Y lebih kecil dari 0.25 maka resiko kredit bernilai sangat tinggi.

\subsection{Diagram Use Case}

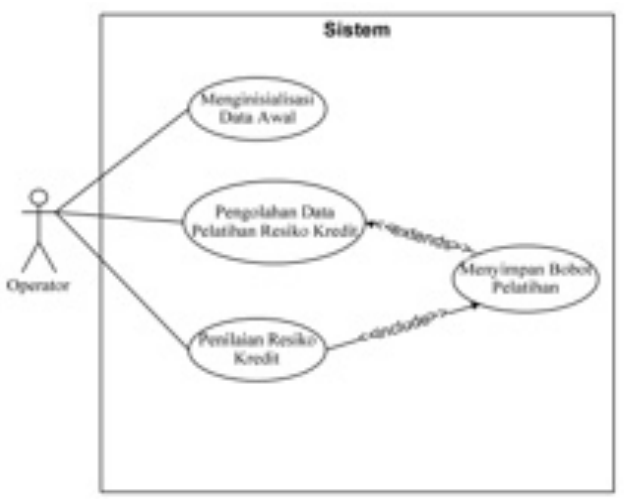

Gambar 4. Diagram Use Case

Tabel 1. Definisi Use Case

\begin{tabular}{|l|l|}
\hline Use Case & Deskripsi \\
\hline Menginisialisasi Data Awal & Proses penginisialisasian jaringan saraf \\
\hline $\begin{array}{l}\text { Pengolahan data pelatihan resiko } \\
\text { kredit }\end{array}$ & $\begin{array}{l}\text { Proses pelatihan data resiko kredit dengan } \\
\text { menggunakan algoritma Backpropagation }\end{array}$ \\
\hline Penilaian resiko kredit & $\begin{array}{l}\text { Proses pengujian evaluasi resiko kredit dengan } \\
\text { menggunakan algoritma Backpropagation }\end{array}$ \\
\hline Menyimpan bobot pelatihan & $\begin{array}{l}\text { Proses penyimpanan bobot yang telah di dapat pada } \\
\text { proses pelatihan kedalam database }\end{array}$ \\
\hline
\end{tabular}

3.4 Kelas Analisis Use Case Keseluruhan

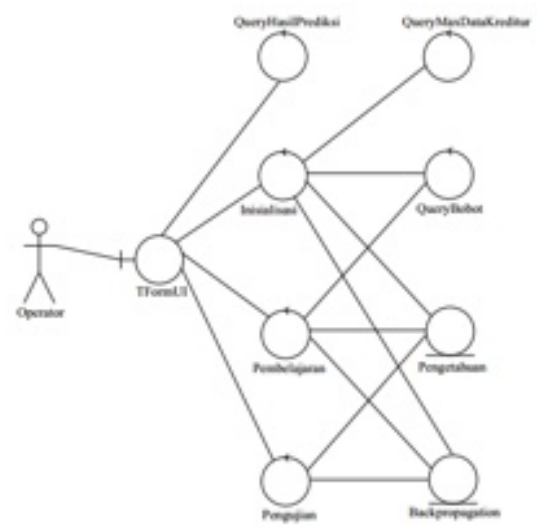

Gambar 5. Kelas Analisis Keseluruhan 


\subsection{Sequence Diagram}

\subsubsection{Sequence Diagram Use Case Menginisialisasi Data Awal}

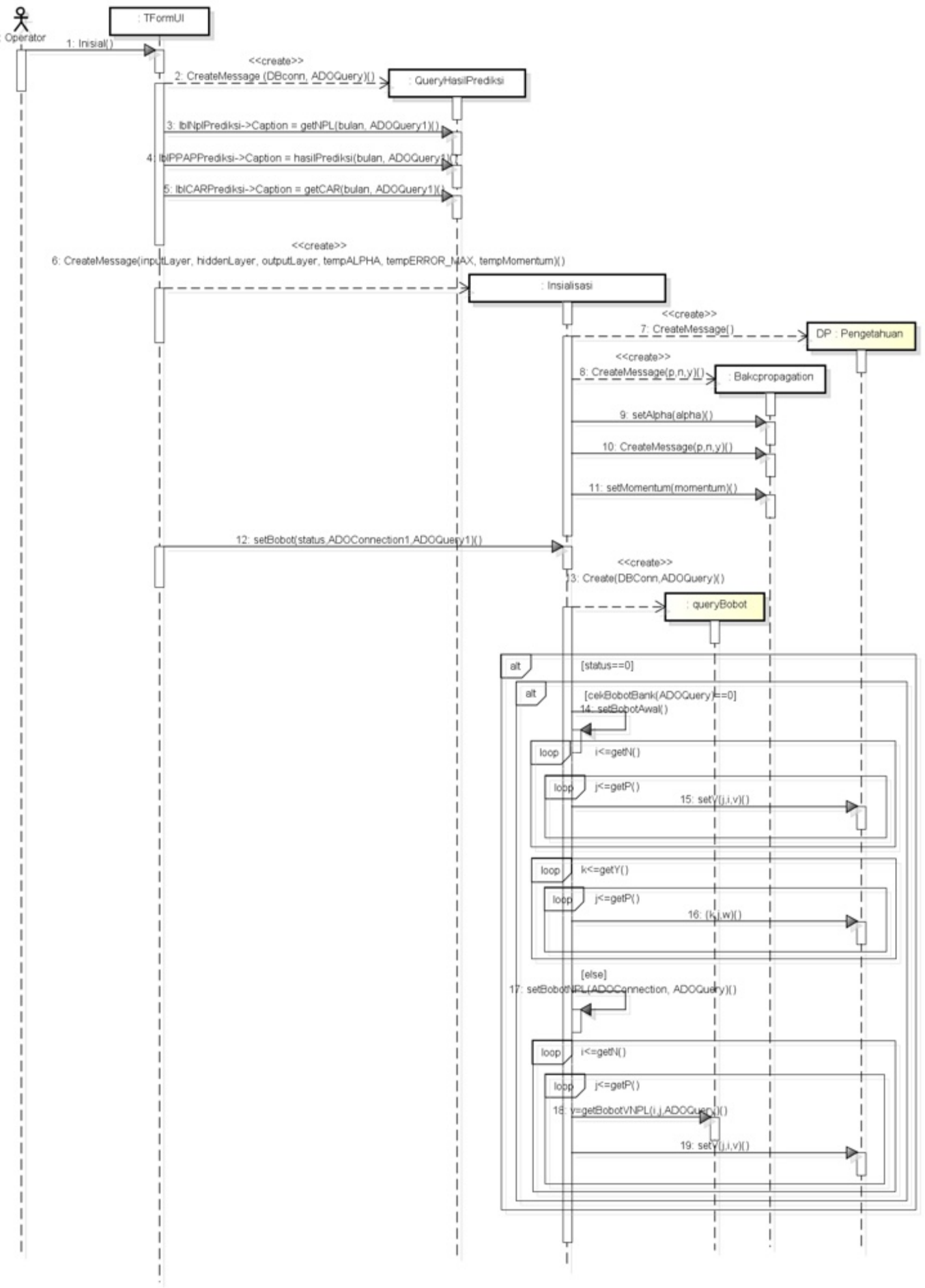

Gambar 6. Sequence Diagram Use Case Menginisialisasi Data Awal 
Computatio: Journal of Computer Science and Information Systems, Volume 2, No 1, April 2018

3.5.2 Sequence Diagram Use Case Pengolahan Data Pelatihan Resiko Kredit

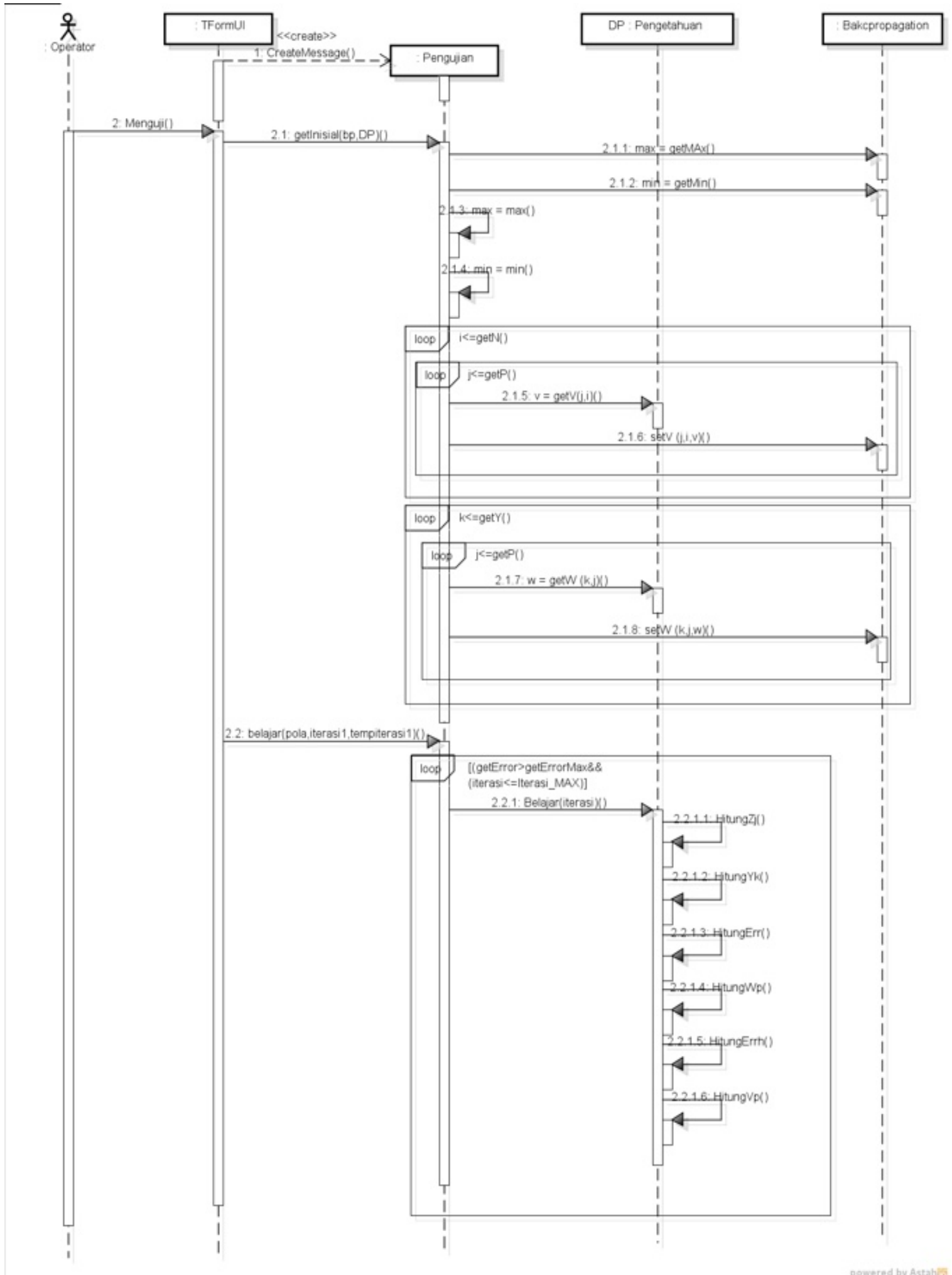

Gambar 7. Sequence Diagram Use Case Pengolahan Data Pelatihan Resiko Kredit 


\subsubsection{Sequence Diagram Use Case Penilaian Resiko Kredit}

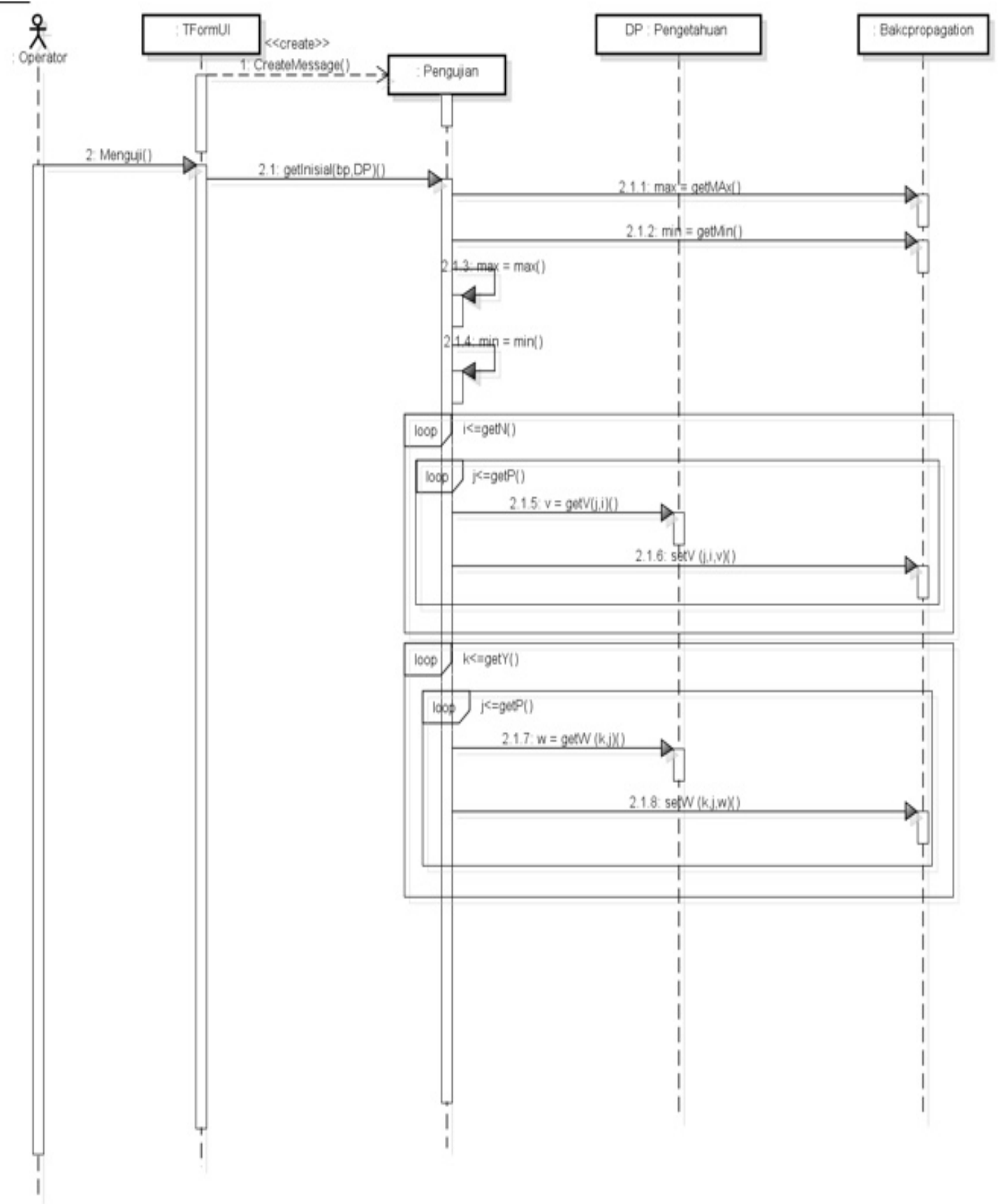

Gambar 8. Sequence Diagram Use Case Penilaian Resiko Kredit 
Computatio: Journal of Computer Science and Information Systems, Volume 2, No 1, April 2018

3.5.4 Sequence Diagram Use Case Menyimpan Bobot Pelatihan

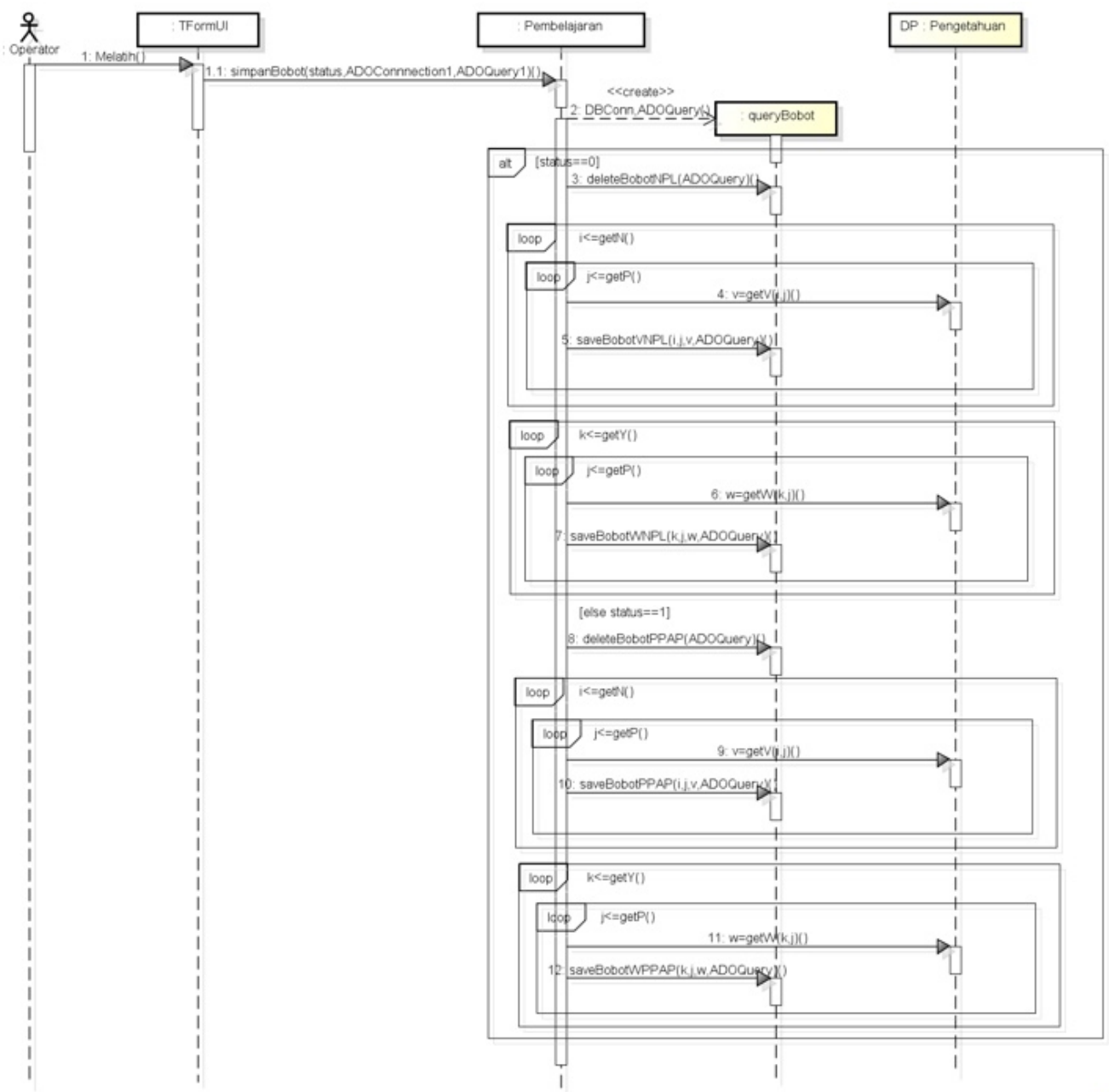

Gambar 9. Sequence Diagram Use Case Menyimpan Bobot Pelatihan

3.6 Perancangan Antar Muka

3.6.1 Perancangan Antar Muka Pelatihan Data Bank

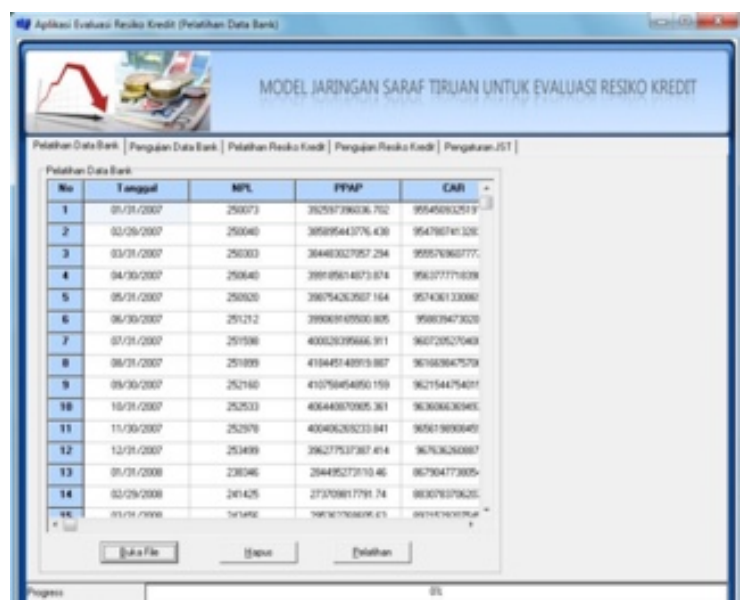

Gambar 11. Antar Muka Pelatihan Data Bank 


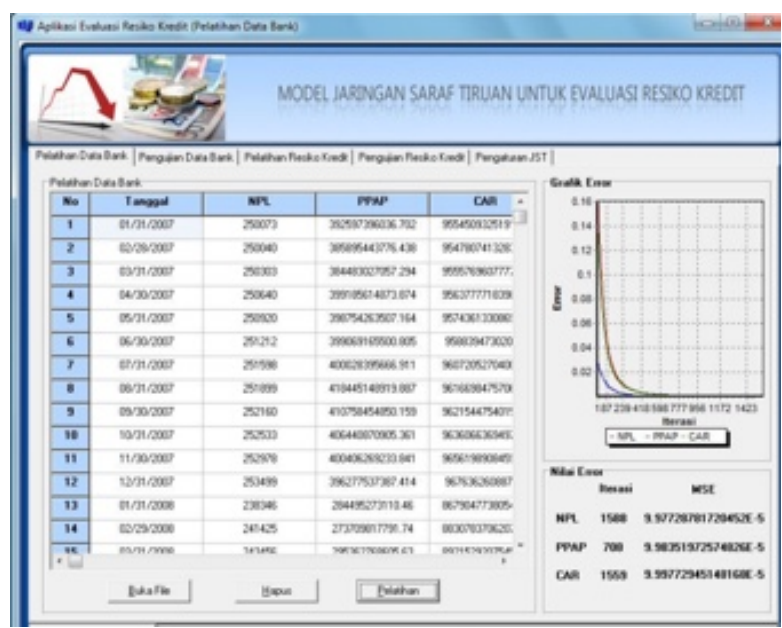

Gambar 12. Antar Muka Hasil Data Pelatihan bank

3.6.2 Antar Muka Pengujian Data Bank

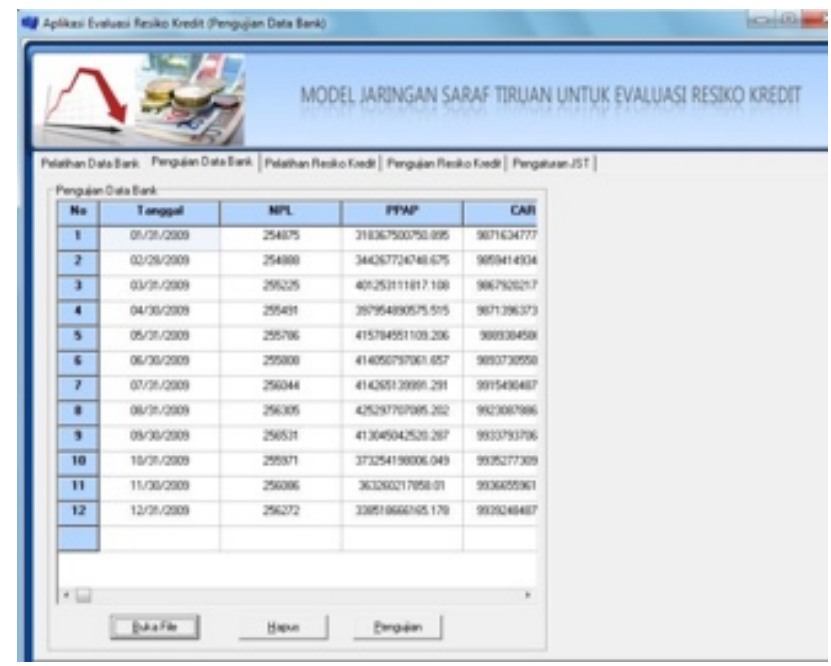

Gambar 13. Antar Muka Pengujian Data Bank

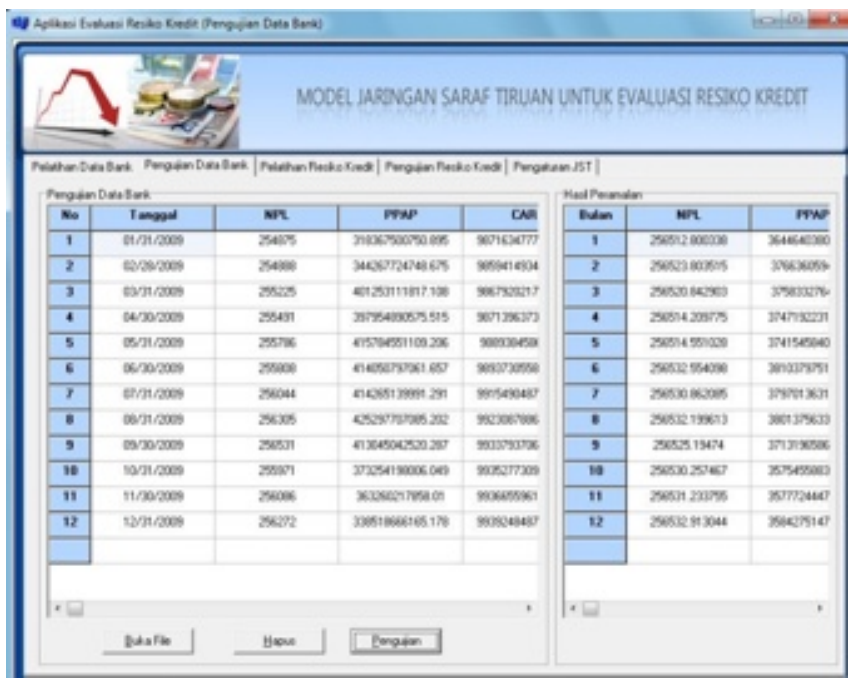

Gambar 14. Antar Muka Hasil Pengujian Data Bank 
Computatio: Journal of Computer Science and Information Systems, Volume 2, No 1, April 2018

3.6.3 Antar Muka Pelatihan Resiko Kredit

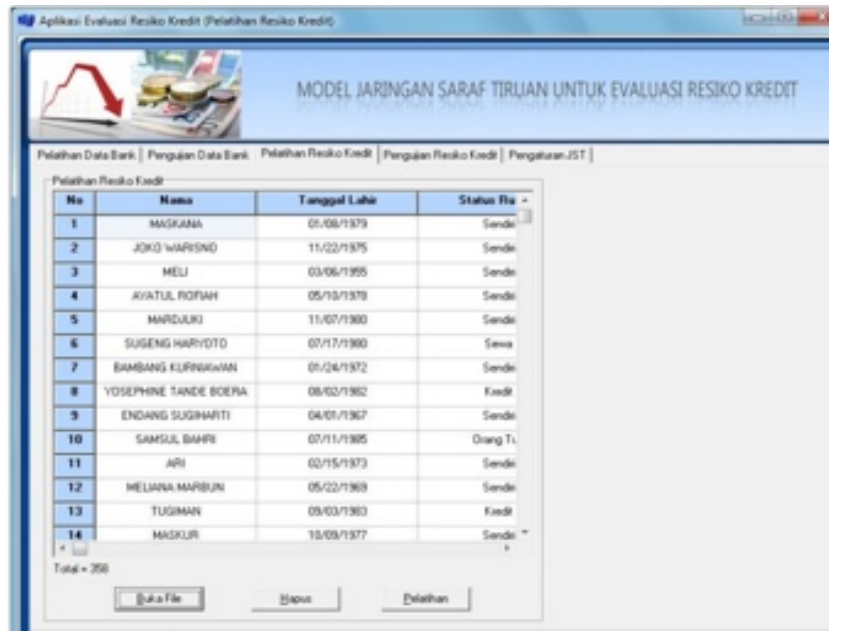

Gambar 15. Antar Muka Pelatihan Resiko Kredit

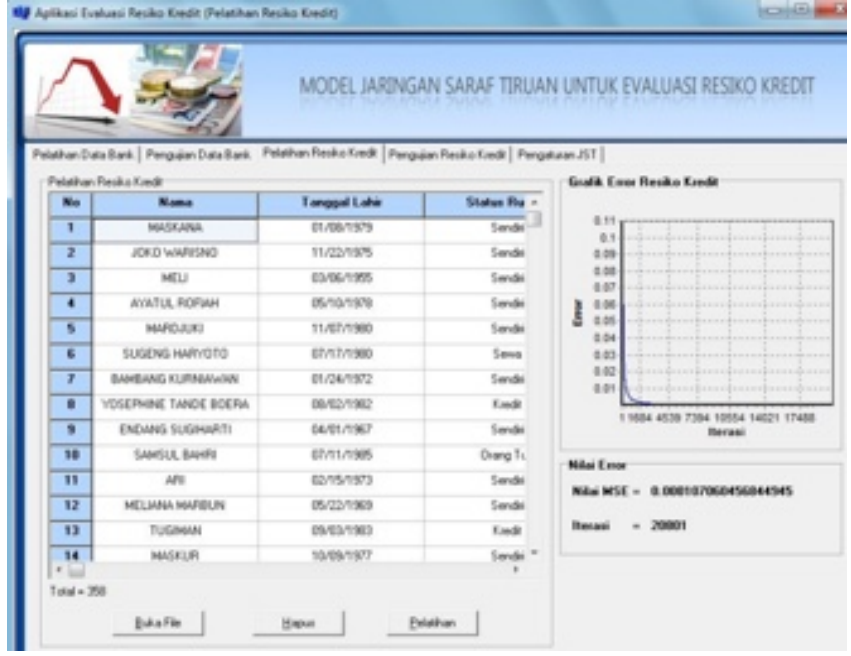

Gambar 16. Antar Muka Hasil Pelatihan Resiko Kredit

3.6.4 Antar Muka Pengujian Resiko Kredit

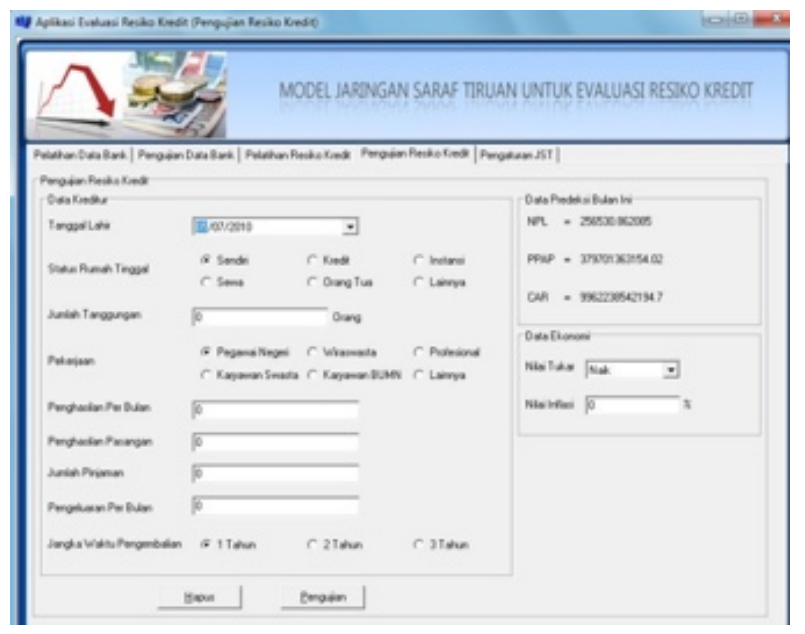


Gambar 17. Antar Muka Pengujian Resiko Kredit

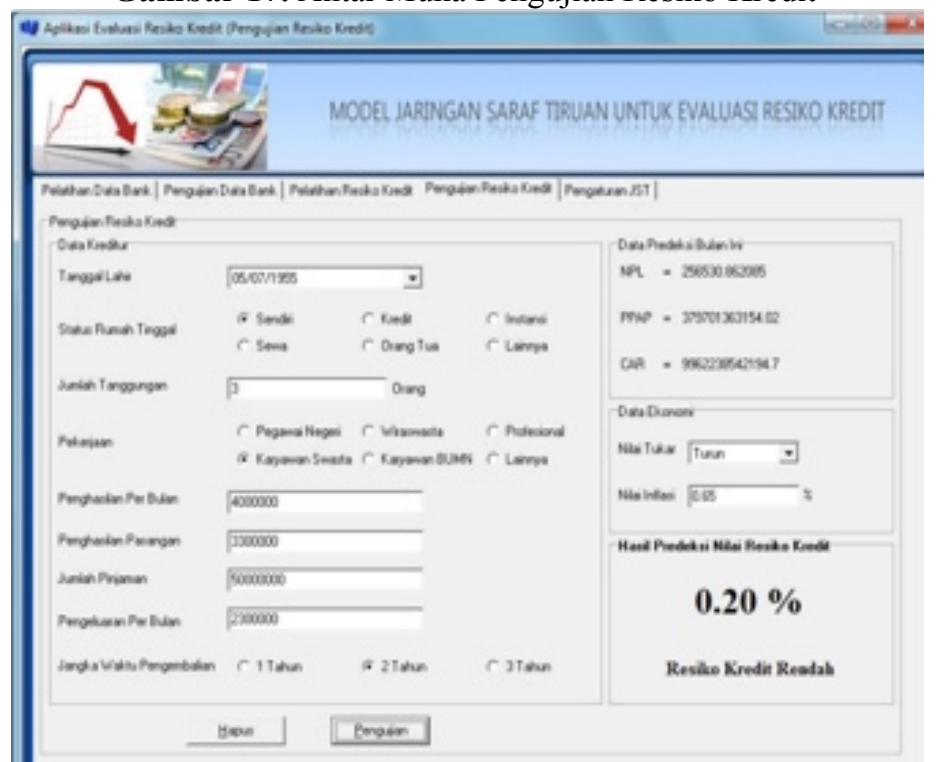

Gambar 18. Antar Muka Haisl Pengujian Resiko Kredit

\subsection{Hasil Pengujian}

Setelah melakukan beberapa kali proses pembelajaran dan pengujian evaluasi resiko kredit, maka didapatkan hasil pengujian yang cukup baik dengan menggunakan pemodelan jaringan saraf tiruan sebagai berikut :

Tabel 2. Hasil Pengujian

\begin{tabular}{|c|c|c|c|c|c|c|c|c|}
\hline No & $\begin{array}{c}\text { Hidden } \\
\text { Layer }\end{array}$ & $\begin{array}{c}\text { Kecepatan } \\
\text { Pembelajaran }\end{array}$ & Momentum & $\begin{array}{c}\text { Minimum } \\
\text { Error }\end{array}$ & $\begin{array}{c}\text { Keakuratan } \\
\text { Prediksi } \\
\text { NPL }\end{array}$ & $\begin{array}{c}\text { Keakuratan } \\
\text { Prediksi } \\
\text { PPAP }\end{array}$ & $\begin{array}{c}\text { Keakuratan } \\
\text { Prediksi } \\
\text { CAR }\end{array}$ & $\begin{array}{c}\text { Keakuratan } \\
\text { Resiko } \\
\text { Kredit }\end{array}$ \\
\hline 1 & 9 & 0.00935 & 0.67 & 0.003 & $99 \%$ & $73 \%$ & $99 \%$ & $86 \%$ \\
\hline 2 & 9 & 0.00935 & 0.67 & 0.001 & $99 \%$ & $73 \%$ & $99 \%$ & $86 \%$ \\
\hline 3 & 10 & 0.00935 & 0.67 & 0.001 & $99 \%$ & $76 \%$ & $98 \%$ & $83 \%$ \\
\hline 4 & 9 & 0.00935 & 0.67 & 0.0001 & $99 \%$ & $75 \%$ & $96 \%$ & $88 \%$ \\
\hline 5 & 9 & 0.00935 & 0.67 & 0.00001 & $99 \%$ & $76 \%$ & $95 \%$ & $86 \%$ \\
\hline 6 & 9 & 0.001 & 0.67 & 0.0001 & $99 \%$ & $75 \%$ & $96 \%$ & $85 \%$ \\
\hline 7 & 9 & 0.00935 & 0.1 & 0.0001 & $99 \%$ & $75 \%$ & $96 \%$ & $86 \%$ \\
\hline 8 & 9 & 0.00935 & 0.01 & 0.0001 & $99 \%$ & $75 \%$ & $96 \%$ & $87 \%$ \\
\hline
\end{tabular}

Berdasarkan hasil pengujian dari tabel diatas, didapatkan hasil prediksi yang paling baik adalah nilai $88 \%$, dengan hidden layer sebanyak 9, nilai kecepatan pembelajaran sebesar 0.00935 , nilai momentum sebesar 0.67 dan nilai minimum error sebesar 0.0001

\section{KESIMPULAN}

Berdasarkan hasil analissi dan implementasi yang telah dilakukan, maka dapat diambil kesimpulan yaitu pemodelan jaringan saraf tiruan dapat digunakan untuk mengevaluasi rresiko kredit dengan menggunakan faktor data bank yang menjadi indikator dalam menilai kredit perbankan, faktor ekonomi berupa nilai inflasi dan nilai tukar mata uang, dan data-data krediur. 
Serta dari hasil pengujian dari resiko kredit mendapatkan keakuratan sebesar $88 \%$, untuk nilai NPL 99\%, untuk nilai PPAP 75\% dan nilai CAR 96\%.

\section{DAFTAR PUSTAKA}

[1] H. Leidiyana, "Penerapan Algoritma K-Nearest Neighbor Untuk Penentuan Resiko Kredit Kepemilikan Kendaraan Bemotor," J. PIKSEL, vol. 1, no. 1, pp. 65-76, 2013.

[2] F. Pakaja, A. Naba, and Purwanto, "Peramalan Penjualan Mobil Menggunakan Jaringan Syaraf Tiruan dan Certainty Factor," J. EECCIS, vol. 6, no. 1, pp. 23-28, 2012.

[3] D. Puspitaningrum, Pengantar Jaringan Saraf Tiruan. Yogyakarta: Andi Offset, 2014.

[4] N. Wijaya, "Capital Letter Pattern Recognition in Text to Speech by Way of Perceptron Algorithm," Knowl. Eng. Data Sci., vol. 1, no. 1, pp. 26-32, 2018.

[5] Z. Arifin, Dasar-Dasar Manajemen Bank Syariah. Tangerang: Azkia, 2009.

[6] Rivai, Veithzal, and V. A. Permata, Credit Management Handbook: Teori, Konsep, Prosedur, dan Aplikasi Panduan Praktis Mahasiswa, Bankir, dan Nasabah. Jakarta: PT. RajaGrafindo Persada, 2006.

[7] N. Wijaya, H. Irsyad, and A. Taqwiym, "Design Verification Using Palmprint," TEKNOMATIKA, vol. 7, no. 2, pp. 36-46, 2017.

[8] P. Kruchten, The rational unified process: an introduction. United States of America: Addison Wesley Professional, 2004. 